\title{
ICT Competence among Academic Staff in Universities in Cross Rivers State, Nigeria
}

\author{
Ijeoma Aniedi Archibong (Correspondent author) \\ Faculty of Education, Cross River University of Technology, Calabar, Nigeria \\ Box 368 H.E.P.O, State Housing Estate Calabar, Cross River State, Nigeria
}

Tel: 234-706-854-8508 E-mail: anije1997@yahoo.com

Joseph E. Ogbiji

Faculty of Education, Cross River University of Technology, Calabar, Nigeria

Box 368 H.E.P.O, State Housing Estate Calabar, Cross River State, Nigeria

Tel: 234-806-485-4436Ｅ-mail: joeogbiji@yahoo.com

Franca Anijaobi-Idem

Faculty of Education, University of Calabar, Nigeria

Box 368 H.E.P.O, State Housing Estate Calabar, Cross River State, Nigeria

Tel: 234-803-654-3636 E-mail: francaanijah@yahoo.com

\begin{abstract}
The survey research design was adopted in this study which examined ICT competence and challenges to ICT usage among academic staff. Six research questions were posed to guide the study and a questionnaire was developed, validated and used for data collection from a sample size of 300 academic staff. The collected data were analysed using descriptive statistics (percentages). The results show that majority of the academic staff funded their ICT training; high number of them have laptops; access to internet was mainly at public cyber café; majority (53.3\%) rated their ICT competence as low. Inadequate ICT facilities, excess work load and funding were identified as major challenges to ICT usage among academic staff. Recommendations made include funding of ICT training of academic staff by the university management and making ICT training mandatory for all academic staff.
\end{abstract}

Keywords: ICT competence, Academic staff, Usage, Training, Challenges

\section{Introduction}

Teachers play a crucial role in the development, adoption and Implementation of any educational curriculum or innovation. This role becomes even more critical in adoption and integration of information and communication technology (ICT) into the education programme of a country. It has been discovered that knowledge of (ICT) usage improves human capacity in every field of human endeavour, including business transaction, industrial operations, educational programmes and activities and life in general. Radloff (2001) highlights the opportunities that ICT presents for enhancing the quality of teaching and learning to include:

- Providing encouragement for staff and students to reflect on how they teach and learn.

- Applying theory and research on learning and principles of good instruction to designing online learning environments.

- Making teaching (and learning) more visible and public.

- Encouraging collaboration and team work among staff (and students).

- Offering greater access to learning for more people.

- Increasing the skills and status of university teachers.

Aware of the significance of ICT educational programmes, governments in the world have adopted several measures to facilitate acquisition of ICT education by enhancement of education and training programme, providing an enabling environment for the development of ICT, provision of incentives for computerisation and automation and creation of venture capital (Pelgrum, and law 2003). Carlson and Gadio (2002) state that teacher 
training in the use of ICT is the best starting point in the ICT policy of a country because they are the key to making learning happen. This according to them is so because teachers who succeed in making use of ICT in their work process, do not only contribute to improved learning outcomes in their students, but may also benefit personally from enhanced work productivity, reduced isolation and increased professional satisfaction. But in a study of 26 education systems (Pelgrum and Anderson 1999), lack of ICT knowledge and skills by teachers was perceived to be a major obstacle for attaining the schools ICT related goals, they equally found that there was a serious lack of skills related to pedagogical ICT use, the most challenging being how to make use of ICT to support and extend learning at the tertiary level of education. Developing teachers' ICT skills is then imperative. Competencies that need to be developed at the early stage of ICT adoption will include according to Pelgrum and Law (2003) the training of teachers in the use of common office application programme, sending of e-mails, making use of the internet, use of ICT in subject based teaching and class room practices. Production of multimedia course materials, data analysis, e-library, video conferencing, networking and e-payments are other areas of competencies that teachers need to develop.

\section{Literature review}

ICT development programme among staff of educational institutions especially at the tertiary educational level is faced by number of obstacles. Prominent among them is the lack of training opportunities for staff. Pelgrum and Anderson (1999) found out that training programme among academic staff is low. Acquiring ICT technical know-how is just the first level, beyond which many training programmes do not go. Gülbahar (2008) in his study found that although pre-service teachers are willing to use technology but this rarely occurred because of the inadequacy of lessons to facilitate them with necessary skills to be technology competent teachers In a study conducted by Banfi (1999), BECTA (2001), 40\% of principals of secondary schools indicate lack of interest among teachers in Czech Republic, Luxembourg, Lithuania and South Africa. Drain of trained teachers to better paid ICT related jobs has been found to be a factor in both developed and developing countries (BECTA, 2001). Computer anxiety and lack of confidence in the use of ICT by teacher in the classroom has been found to be a problem both in U.K, U.S.A. and Australia (Rosen and Maguire, 1995). Juwah and Northcote (2002) in their study found that the reasons adduced by staff for lack of relevant ICT skills include lack of time to attend staff development activities as a result of other work commitments, previous bad experience in IT training and fear of technology. In a study by Archibong and Effiom (2009), lack of interest, limited access to ICT facilities and lack of training opportunities were among the obstacles to ICT usage among academic staff found.

On funding of ICT educational programme for staff, Pelgrum and Law (2003) suggest a collaborator approach between the different levels of government and educational institutions. A study by Jegede (2009) revealed that majority of the respondents who had undergone formal ICT training did so at personal expense and that even where trainings were organised by schools' authorities and computer centres, payments in many of the cases have been from personal purses.

Integrating ICT culture into educational institution is a change which Ringle and Updegrove (1998) advised that the approach should be carried out by incorporating the socio-economic and pragmatic or technical dimensions. This is so because studies in the management of change and innovation (Fullam1993, 2001) have shown that the process of change is a complex one. It involves not only changes in infrastructure and curriculum materials, but more importantly of practice and belief (socio-economic). For a successful implementation of ICT programme in schools, Pelgrum and Law (2003) have suggested the following strategies:

- Provision of training on baseline technical skills for teachers and students.

- Provision of good technology infrastructure including computer access and network connectivity for teachers and students.

- Challenging teacher education institutions to integrate ICT into their teacher education programmes.

- Establishment of centres for learning technology in teacher education institutions to support the systematic integration of ICT for education purpose.

- Stimulation, socialisation and funding of projects on ICT that will develop lifelong learning.

- Engage university research centres in research integrated programmes on the use of ICT in education.

Because lecturers' possession of the requisite knowledge and competence is a necessary prerequisite to achieving any ICT education programme of a nation, the authors of this paper deemed it necessary to determine 
the extent of competence academic staff in universities in Cross River State possess to cope with the technological challenges.

\section{Statement of the problem}

ICT literacy among academic staff has been viewed as a prerequisite in adoption and integration of ICT in the school system. It has however been observed that in universities in Cross River State, ICT usage among lecturers in the teaching and learning situation is still very minimal. This informed the researchers' decision to investigate if this prevailing situation could be attributed to academic staff competence in ICT. This study aims at:

1) Determining the source of funding for staff ICT development programme.

2) Establishing what numbers of academic staff have personal computers or laptops.

3) Determining the main source of access to internet by academic staff.

4) Ascertaining how academic staff rate their ICT competency level

5) Investigating the competency level of academic staff in the use of ICT, and

6) Ascertaining the challenges to academic usage of ICT.

To achieve the stated objectives, the following research questions are posed:

1) What are the major sources of funding for academic staff ICT development programmes?

2) What numbers of academic staff possess personal computers/ laptops?

3) Where do academic staff have access to internet?

4) How do academic staff rate their ICT competency level?

5) What is the ICT competence level academic staff?

6) What are the challenges to ICT usage by academic staff?

\section{Method}

In consonance with the objectives of this study, the survey research design was utilised. The two universities located in Cross River State namely the Cross River University of technology (CRUTECH) and the University of Calabar (UNICAL) were utilised for the study. The target participants were all academic staff in both institutions. In order to avoid being restricted to sampling academic staff in some faculties and leaving others out, the researchers adopted accidental sampling technique so as to enable the researchers to purposively administer the research instrument and have a good mix of academic staff in diverse discipline in the study.

The research instrument was administered to a total of 350 academic staff, only 300 were successfully completed and returned, giving a return rate of $85.7 \%$. Out of this number of academic staff, 120 were from CRUTECH while 180 were from UNICAL. The 300 academic staff consisted of 112 females and 188 males. In terms of rank, the sample comprised 40 Assistant lecturers, 76 lecturers 11, 56 Lecturers 1, 80 Senior lecturers, 24 Readers and 24 Professors.

The research instrument tagged 'ICT Competence Questionnaire (ICOQ) comprised 4 sections. Section A sought demographic information on gender, rank and institution. The 4 items in section B relating to source of funding for staff ICT training, possession of laptop/computer, place of access to internet, and rating of ICT competence required a 'Yes' or 'No' answer. Section C contained 14 items measured in a 4 point Likert-like scale ranging from 'Not competent to 'Very competent' measuring academic staff competence in using ICT for the purposes indicated. Finally section D was open ended requiring academic staff to indicate 2 challenges/obstacles to their ICT usage. The face validation for items in the research instrument was carried out by 2 academic staff that are in the measurement and evaluation discipline. The internal consistency of the research instrument established through the test- retest method using 30 academic staff that were not part of the study sample. This yielded a correlation co-efficient of 0.72 for the entire instrument. Hence, the instrument was considered adequate and significant to the objective of this study. The collected data were analysed using descriptive statistics (percentages).

\section{Results and discussion}

For the purpose of ease of understanding, the results are presented and discussed following the sequence of the research questions. 


\subsection{Source of funding for ICT training}

A look at Table 1 show that $268(89.3 \%)$ of academic staff funded any form of ICT development training they have undertaken. While only $32(10.7 \%)$ academic staff have received assistance from the University in ICT-related development training. This finding implies that institutional commitment to staff development in ICT is very minimal as only $10.7 \%$ of the respondents have had institutional assistance in funding their ICT development. This finding brings to bear the position of Carlson and Gadio (2002) that while teacher professional development is woefully underfunded generally, the situation of training in technology is much worse, as policy makers operating within budget constraints tend to give priority to hardware and software acquisition. Their observation holds true for the two institutions used in this study as both have little or no effort towards funding of training of academic staff in ICT.

\subsection{Ownership of computers (desktop/laptop)}

Results in Table 2 show that 208(69.3\%) of the respondents have personal computers/laptop, while 92(30.7\%) did not. The high percentage of academic staff computers/laptops can be attributed to the fact that the Cross River State government encouraged staff interest in ICT by allowing staff buy computers (desktop/laptop) and pay by instalment over a period of two years. Again, CRUTECH received donations of laptops from some organisations which have been distributed to heads of departments and examination officers. Besides, some academic staff are beginning to see the need to own a personal computer.

\subsection{Access to internet}

With regards to access to internet the results show that $187(62.3 \%)$ of the respondents access internet at pubic cyber café. This is followed by those that have private means $93(31 \%)$, while those that access internet at the school are the least $20(6.7 \%)$. The high patronage of public cyber café to access internet by academic staff could be explained by the non functionality of the cyber café in CRUTECH and the overcrowding of the cyber café by students in UNICAL. It is however encouraging to note that some academic staff creating their own means of access to the internet by buying the modem and air time from internet service providers.

\subsection{Rating of ICT competence}

The results in Table 4 show that only 20(6.7\%) of the academic staff in this study rated their ICT competency level as high. Those with moderate competency level were $120(40 \%)$, while the majority $160(53.3 \%)$ rated their ICT competency level as low. This result is not encouraging as the combination of staff that rated their competency level as high and moderate (46.7\%) is still lower than those that were low ICT competency level. With this result, the possibility of many academic staff utilising ICT in teaching and learning situation is greatly restricted if non-existent.

\section{5 level of ICT competence}

The findings in Table 5 show that the combination of staff that indicated that they were either competent or very competent in utilisation of ICT in all the indices measured was below fifty percent (50\%). The highest areas of competence indicated by academic staff were in usage of ICT for purposes of research 148 (49.3\%); for e-mail $136(45.3 \%)$ and for word processing $120(40 \%)$. It is disheartening to that in this era of technology, academic staff are still not competent in utilising ICT for common purposes such as e-library, data analysis, e-learning and so on as the statistics in Table 5 reveal. Given this result, it can be said that the competency level of academic staff in utilising ICT is still very low. With the lecturers rating low in utilising ICT, how can we expect to encourage students in this direction? No wonder Carlson and Gadio (2002) posited that teacher training in the use of ICT is the best starting point in ICT policy of a country because they are the key to making learning happen.

\subsection{Challenges to ICT usage}

As can be seen in Table a wide array of challenges to ICT usage has been indicated by the academic staff. A critical look at Table 6 however indicates that these the challenges can be summarised as follows:

- Funding-related challenge: From the results, it seems that many academic staff are reluctant to use their salaries for the purpose acquiring training in ICT. The other dimension is that there is little or no sponsorship from the university as earlier revealed in the study, therefore making funding an issue the acquisition of ICT knowledge among academic staff.

- Facility-related challenge: Access and proximity to ICT facilities pose problem to academic staff. Even those that are ICT literate lack the necessary facilities at their workplaces. Electricity supply which is critical to the usage of ICT facilities is very epileptic in Nigeria which makes the ownership of a power 
generator mandatory for ICT users. This fact coupled with financial constraints pointed out earlier indicates why electricity is a major obstacle in the use of ICT by academic staff. This result is similar to earlier finding by Archibong and Effiom (2009) in which academic staff revealed that power failures and inaccessibility of ICT facilities as obstacles to their ICT usage.

- Workload and academic staff personal disposition to ICT: In analysing the questionnaire, most senior academics, from the ranks of Senior Lecturer to Professors cited excess workload which does not give them time to train or even improve upon their ICT skills as a challenge. It is however not encouraging to note that some academic lack interest in ICT while some are unwilling to exercise patience to learn.

\section{Conclusion}

From the findings of this study, it was concluded that ICT skills development undertaken by academic staff was mainly self-funded. In essence funding from the university towards staff ICT development was very minimal. The study equally revealed that relatively high percentage of academic staff have personal computer, indicating their interest in acquisition of ICT skills. Again, access to internet by academic staff was mainly at public cyber café compared to private and school, indicating inadequacy of such facilities on campus. Majority of the academic staff in this study rated their ICT competence as low. In terms of ICT usage, the highest areas of competence were in research, e-mail and word processing, while their competences in the other areas studied were low. Finally, it was also concluded that the major challenges to ICT usage among academic staff were related to funding, facilities and work load.

\section{Recommendations}

Based on the findings and the conclusions drawn in this study, it is hereby recommended that the university management should fund the ICT training of academic staff. Furthermore, provision should be made for continuous retraining of staff on ICT since development in technology is dynamic and the staff need to keep abreast with current trends. Again, the university management should make training in ICT mandatory for all academic staff as this will propel the uninterested or unwilling ones to undertake the training. Lastly, ICT facilities should be provided and its functionality ensured so as to improve academic staff access to it within the campuses. Finally, it is suggested that academic staff should have a rethink towards ICT training and make time to improve their competences irrespective of their workload.

\section{References}

Archibong, I. A. and Effiom, D. O. (2009). ICT in University Education: Usage and Challenges among Academic Staff. African Research Review, 3(2): pp 404-414.

Banfi, I. (1999). Hungary. In W.J. Pelgrum \& R. Anderson (Eds), ICT and the Emerging Paradigm for Lifelong Learning (pp. 47 -48). Amsterdam: IEA.

BECTA. (2001). Emerging Findings from the Evaluation of the Impact of ICT on Pupils Attainment. London: BECTA.

Carlson, S. and Gadio, C. T. (2002). Teacher Professional Development in the use of ICT. In Haddad, W. D. \& Draxler, A. (Eds.), Technology for Education. (pp. 118 - 132). Washington, DC: UNESCO; Academy for Educational Development.

Fullan, M. (1993). Change Forces: Probing the Depth of Educational Reform. London: Palmer Press.

Fullan, M. (2001). Leading in a Culture of Change. San Francisco: Jossey Bass.

Gülbahar, Y. (2008). ICT Usage in Higher Education: A Case Study on Preservice Teachers and Instructors. The Turkish online journal of educational technology- TOJET v7 n1 article 3 Jan 2008.

Jegede, P. O. (2009). Assessment of Nigerian Teacher Educators' ICT Training. Issues in Informing Science and Information Technology, 6: pp 415-420.

Juwah, C. and Northcote, M. (2002) Devising Strategies for Enhancing Quality Staff Development in Embedding ICT in Teaching and Learning, in Quality Conversations, Proceedings of the $25^{\text {th }}$ HERDSA Annual Conference, Perth, Western Australia, 7-10 July 2002: pp 384-392

Pelgrum, W.J. and Anderson, R.E. (1999) (Eds.) ICT and Emerging Paradigm for Lifelong Learning. Amsterdam: IEA.

Pelgrum, W.J. and Law, N. (2003). ICT in Education Around the World: Trends, Problems and Prospects. Paris: UNESCO. 
Radloff, A. (2001). Getting Online: The Challenges for Academic Staff and Institutional leaders. Retrieved 19 August 2008 from http://www.ascilite.org.au/conferences/melbourne01/pdf/papers/radloffa.pdf

Ringle, M. and Updegrove, D. (1998). Is Strategic Planning for Technology an Oxymoron? CAUSE/EFFECT, 21(1): pp 18-23.

Rosen, I. D., \& Maguire, P. (1995). Computer anxiety: A cross-cultural comparison of university students in ten countries. Computers in Human Behaviour, 11(1): pp 45-64.

Table 1. Funding sources for ICT training among academic staff $(\mathrm{N}=300)$

\begin{tabular}{|l|c|c|}
\hline Funding sources & Number & Percentage (\%) \\
\hline Self & 268 & 89.3 \\
\hline University & 32 & 10.7 \\
\hline
\end{tabular}

Table 2. Respondents' ownership of personal computers $(\mathrm{N}=300)$

\begin{tabular}{|c|c|c|}
\hline Ownership of computer/laptop & Number & Percentage (\%) \\
\hline Yes & 208 & 69.3 \\
\hline No & 92 & 30.7 \\
\hline
\end{tabular}

Table 3. Respondents' access to internet $(\mathrm{N}=300)$

\begin{tabular}{|l|c|c|}
\hline Place of access to internet & Number & Percentage (\%) \\
\hline School & 20 & 6.7 \\
\hline Public cyber café & 187 & 62.3 \\
\hline Private & 93 & 31.0 \\
\hline
\end{tabular}

Table 4. Academic staff rating of ICT competency level $(\mathrm{N}=300)$

\begin{tabular}{|l|c|c|}
\hline Rating of competency level & Number & Percentage (\%) \\
\hline High & 20 & 6.7 \\
\hline Moderate & 120 & 40.0 \\
\hline Low & 160 & 53.3 \\
\hline
\end{tabular}


Table 5. Respondents' rating of ICT usage skills $(\mathrm{N}=300)$

\begin{tabular}{|l|l|l|l|l|l|}
\hline \multicolumn{1}{|c|}{ ITEMS } & $\begin{array}{l}\text { Not } \\
\text { Competent } \\
\text { Frequency (\%) }\end{array}$ & $\begin{array}{l}\text { Somewhat } \\
\text { Competent } \\
\text { Frequency (\%) }\end{array}$ & $\begin{array}{l}\text { Competent } \\
\text { Frequency (\%) }\end{array}$ & $\begin{array}{l}\text { Very } \\
\text { Competent } \\
\text { Frequency (\%) }\end{array}$ & $\begin{array}{l}\text { Competent } \\
+ \\
\text { Very } \\
\text { Competent } \\
\text { Frequency (\%) }\end{array}$ \\
\hline Word processing & $76(25.3)$ & $104(34.7)$ & $100(33.3)$ & $20(6.7)$ & $120(40.0)$ \\
\hline e- mail & $72(24.0)$ & $92(30.7)$ & $96(32.0)$ & $40(13.3)$ & $136(45.3)$ \\
\hline Research & $48(16.0)$ & $104(34.7)$ & $104(34.7)$ & $44(14.6)$ & $148(49.3)$ \\
\hline Data analysis & $152(50.7)$ & $76(25.3)$ & $48(16.0)$ & $24(8.0)$ & $72(24.0)$ \\
\hline Power point presentation & $120(40.0)$ & $100(33.3)$ & $56(18.7)$ & $24(8.0)$ & $80(26.7)$ \\
\hline e- library & $176(58.7)$ & $64(21.3)$ & $48(16.0)$ & $12(4.0)$ & $60(20.0)$ \\
\hline e- payments & $176(58.7)$ & $68(22.7)$ & $52(17.3)$ & $4(1.3)$ & $56(18.6)$ \\
\hline e-learning (online courses) & $188(62.7)$ & $64(21.3)$ & $36(12.0)$ & $12(4.0)$ & $48(16.0)$ \\
\hline Course preparation & $112(37.2)$ & $84(28.0)$ & $84(28.0)$ & $20(6.7)$ & $104(24.7)$ \\
\hline Development of proposals & $136(45.3)$ & $56(18.7)$ & $96(32.0)$ & $12(4.0)$ & $108(36.0)$ \\
\hline $\begin{array}{l}\text { Notes online/ giving } \\
\text { assignments }\end{array}$ & $156(52.0)$ & $84(28.0)$ & $40(13.3)$ & $20(6.7)$ & $60(20.0)$ \\
\hline Video conferencing & $212(70.7)$ & $64(21.3)$ & $16(5.3)$ & $8(2.7)$ & $24(8.0)$ \\
\hline Mobile phone browsing & $136(45.3)$ & $60(20.0)$ & $84(28.0)$ & $20(6.7)$ & $104(34.7)$ \\
\hline Networking (face book) & $176(58.7)$ & $84(28.0)$ & $36(12.0)$ & $4(1.3)$ & $40(13.3)$ \\
\hline
\end{tabular}

Table 6. Challenges to ICT usage among academic staff

- Lack of funds

- Lack of sponsorship by the school management

- Proximity to ICT facilities

- Inability to acquire personal ICT facilities

- No ICT facilities at workplace

- Poor electricity supply

- Lack of ICT knowledge

- Insufficient time due workload

- No patience to learn

- No interest in learning

- Personal office not secure to install ICT facilities

- No opportunity for training

- Lack of time for practice 